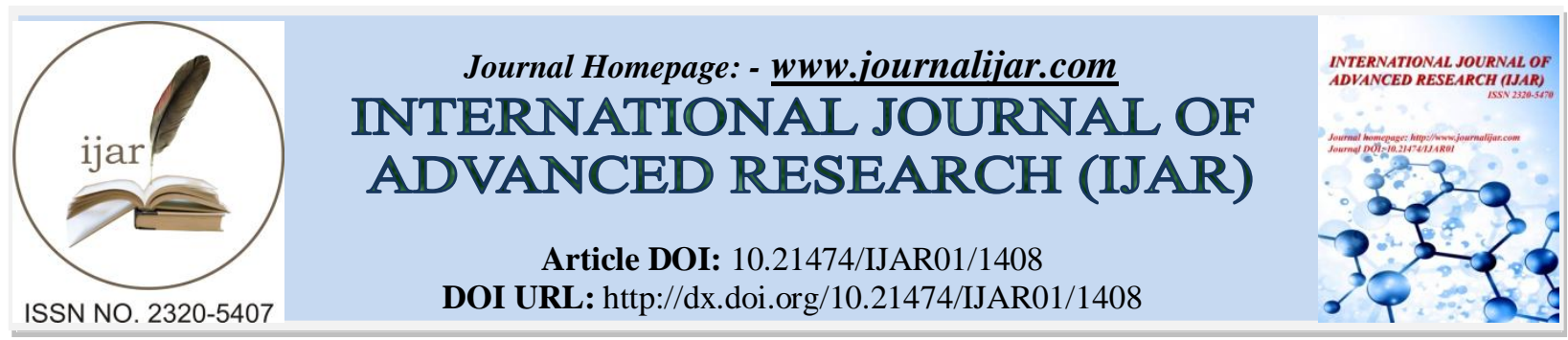

RESEARCH ARTICLE

\title{
DETERMINATION OF PHYSIOCHEMICAL PROPERTIES OF WELL WATER IN OZORO, ISOKO NORTH LOCAL GOVERNMENT AREA OF DELTA STATE.
}

Sawere B. T and Ibuku A. U.

Department of Science Laboratorry, Delta State Polytechnic, Ozoro.

\section{Manuscript Info}

Manuscript History

Received: 12 June 2016

Final Accepted: 19 July 2016

Published: August 2016

Key words:-

physiochemical, well water, Ozoro town..

\section{Abstract}

Safe drinking water is a basic need for good health, and it is also a basic right of humans. Ten samples of well water in Ozoro town were analyzed for physiochemical properties. The $\mathrm{pH}$ values were between 6.6-7.1, within the WHO recommended range. The conductivity values ranged from 0.1-0.5ppm, TDS value ranged from 0.47-1.70. zinc ranged from $(\mathrm{Zn}) 0.01 \pm 0.02$, iron $(\mathrm{Fe}) 0.00 \pm 0.01$ to $0.10 \pm 0.02$, lead $(\mathrm{Pb})$ between $0.00 \pm 0.00$ to $0.02 \pm 0.01$ and for copper it ranged from $0.00 \pm 0.01$ to $0.06 \pm 0.00$ all the values were below $\mathrm{WHO}$ maximum accepted concentration.

Copy Right, IJAR, 2016,. All rights reserved.

\section{Introduction:-}

Water and its management will continue to be a major issue with definite and profound impact on our lives and that of our planet earth (Herschy, 1999). Water is the most important natural resources without which life would be nonexistent. Availability of safe and reliable source of water is an essential prerequisite for sustainable development. Deserts are not habitable because of lack of water (Asonye et al., 2007).Safe drinking water is a basic need for good health, and it is also a basic right of humans. Fresh water is alreadya limiting resource in many parts of the world. In the next century, it will become even more limiting due toincreased population, urbanization, and climate change (Jackson et al. 2001).

Freshwater quality and availability remain one of the most critical environmental and sustainability issues of the twenty-first century (UNEP, 2002). Of all sources of freshwater on the earth, groundwater constitutes over $90 \%$ of the world's readily available freshwater resources (Boswinkel, 2000) with remaining 10\% in lakes, reservoirs, rivers and wetlands.

Deterioration of drinking water quality arises from introduction of chemical compounds into the water supply system through leaks and crossconnection (Napacho and Manyele 2010).Pollution of water bodies with heavy metals from variety of sources is becoming a matter of globalconcern (Dike et al., 2004). Though effects of chemical contamination of drinking water are not felton short-term bases (except nitrate), their accumulation over a long period in the body hassignificant health effects (Musa et al., 2004).Due to massive influx of people from other parts of Nigeria to Ozoro metropolis for further educational pursuit, the population of Ozoro hasincreased andthere is annual population increased. Therefeore, there is an increase in the demand of waterresulting in concomitant acute water shortage to meet thedaily water consumption needs of the people. Most of theresidents have resorted to depend on well waterboth for domestic and industrial usage. The aim of this research is to compare the valuesobtained for the above stated physiochemical parameterswith W.H.O. standard values in order to determine

Corresponding Author:- Sawere B. T

Address:- Department of Science Laboratorry, Delta State Polytechnic, Ozoro. 
thepalatability or otherwise of well water for domestic purposes in Ozoro, isoko north local government area of Delta State, Nigeria.

\section{Materials and methods:-}

The methods employed for this study are sampling and laboratory analysis. A detailed field sampling exercise was carried out, while laboratory analyses of the water samples were carried out at Emma-Maria scientific laboratory, Ozoro.

Location of research:- this study was conducted in Ozoro town the head quarter of isoko north local government area, one of the two administrative units in isoko region of delta state, southern Nigeria. Ozoro town is one of the largest communities in isoko land both in land mass and population. It lies between longitude $6^{\circ} 12^{1} 58^{11} \mathrm{E}$ and latitude $5^{\mathrm{o}} 3^{1} 18^{11} \mathrm{~N}$ (www.wikipedia.org).

\section{Collection of samples:-}

Ten well borehole water samples were collected randomly from different locations in Ozoro metropolis into sterile container and transported to the laboratory for further study within 6 hours of sample collection.

\section{Physiochemical analysis:-}

$\mathrm{pH}$ of the different water samples were determined using Jenway $\mathrm{pH}$ meter, taste and odour were physically determined. Conductivity was determined using conductivity meter, total dissolved solids (TDS) were analyzed using Hanna (TDS) meter. Total hardness was determined using titration methods. Chemical parameterssuch as: nitrate (NO3-), nitrite (NO2-), carbonate (CO3) were also analyzed for each water sample.

\section{Determination of heavy metals:-}

Complete digestion of the well water samples was carried out with nitric acid in a fume chamber. Metals in well water samples were analyzed in accordance with the standard methods of analysis of water samples (AOAC 2002).

\section{Statistical Analysis:-}

Data were expressed as the mean of triplicates \pm SEM. Means were analyzed using a one-way analysis ofvariance (ANOVA). All the statistical analyses were done using SPSS, Version 16.0.

\section{Results and discussion:-}

Physical Test Result:-

\begin{tabular}{|l|l|l|l|l|l|l|}
\hline SN & SAMPLES & PH & TASTE & ODOUR & $\begin{array}{l}\text { CONDUCTIVITY } \\
(\mathbf{p p m})\end{array}$ & TDS (ppm) \\
\hline $\mathbf{1}$ & S1 & 6.8 & Tasteless & Musty & 0.2 & 0.97 \\
\hline $\mathbf{2}$ & S2 & 6.9 & Tasteless & Odorless & 0.4 & 0.77 \\
\hline $\mathbf{3}$ & S3 & 7.1 & Tasteless & Odorless & 0.3 & 1.32 \\
\hline $\mathbf{4}$ & S4 & 6.6 & Tasteless & Chlorine odor & 0.5 & 1.70 \\
\hline $\mathbf{5}$ & S5 & 6.7 & Salty & Odorless & 0.1 & 0.47 \\
\hline $\mathbf{6}$ & S6 & 6.9 & Tasteless & Odorless & 0.3 & 1.64 \\
\hline $\mathbf{7}$ & S7 & 7.0 & Tasteless & Odorless & 0.1 & 0.53 \\
\hline $\mathbf{8}$ & S8 & 7.0 & Tasteless & Odorless & 0.3 & 1.63 \\
\hline $\mathbf{9}$ & S9 & 6.9 & Tasteless & Chlorine odor & 0.3 & 1.15 \\
\hline $\mathbf{1 0}$ & S10 & 6.9 & Tasteless & Earthy & 0.4 & 1.51 \\
\hline
\end{tabular}

$\mathrm{PH}$ is an important parameter in evaluating the acid-basebalance of water. It is also the indicator of acidic or alkalinecondition of water status. WHO has recommendedmaximum permissible limit of $\mathrm{pH}$ from 6.5 to 8.5 . Thecurrent investigation ranges were 6.6- 7.1 which are inthe range of WHO standards. The overall result indicatesthat the Ozoro well water source is within thedesirable and suitable range.

Taste is another important parameter in evaluating the uniqueness of water, all the water samples tested organoleptically were tasteless except for sample 5 which has a salty taste which could be as a result of dissolved chemicals beneath the earth surface where the well is dug. Some substances such as certain organic salts produce a 
taste without an odor and can be evaluated by a taste test. Many other sensations ascribed to the sense of taste actually are odors, even though the sensation is not noticed until the material is taken into the mouth.

Six (6) out of the ten water samples tested were odorless while sample 1 has a musty odor, sample 2 an earthy odor which can be as a result of unavailability of a concrete ring inside the well and the presence of dust from the environment due to the fact that there is no covering on top of the well. Sample 4 and 9 has a chlorinated odor. Musty, earthy and chlorinated odour are unpleasant signs of water qualityproblems, but usually not of harmful contaminants in the water.

Other analysis such as conductivity, total dissolved solids, falls within the maximum permitted level with reference to Nigeria drinking water standard.

Minerals and Heavy Metals

\begin{tabular}{|l|l|l|l|l|l|l|l|l|}
\hline $\mathbf{S N}$ & $\mathbf{S A M P L E S}$ & $\begin{array}{l}\mathbf{C o}_{3} \\
(\mathbf{m g} / \mathbf{l})\end{array}$ & $\begin{array}{l}\mathbf{N o}_{3} \\
(\mathbf{m g} / \mathbf{l})\end{array}$ & $\begin{array}{l}\mathbf{N O}_{\mathbf{2}} \\
(\mathbf{m g l l})\end{array}$ & $\mathbf{Z n}(\mathbf{m g} / \mathbf{l})$ & $\mathbf{F e}(\mathbf{m g} / \mathbf{l})$ & $\begin{array}{l}\mathbf{C u} \\
(\mathbf{m g} / \mathbf{l})\end{array}$ & $\mathbf{P b}(\mathbf{m g} / \mathbf{l})$ \\
\hline $\mathbf{1}$ & $\mathbf{S 1}$ & $1.03 \pm 0.05$ & $1.19 \pm 0.08$ & $0.04 \pm 0.02$ & $0.04 \pm 0.03$ & $0.07 \pm 0.02$ & $0.03 \pm 0.02$ & $0.00 \pm 0.01$ \\
\hline $\mathbf{2}$ & $\mathbf{S 2}$ & $2.03 \pm 0.04$ & $0.16 \pm 1.03$ & $0.02 \pm 0.01$ & $0.02 \pm 0.02$ & $0.05 \pm 0.01$ & $0.02 \pm 0.01$ & $0.01 \pm 0.00$ \\
\hline $\mathbf{3}$ & $\mathbf{S 3}$ & $1.01 \pm 1.00$ & $1.09 \pm 1.00$ & $0.05 \pm 0.00$ & $0.04 \pm 0.01$ & $0.03 \pm 0.05$ & $0.03 \pm 0.01$ & $0.01 \pm 0.01$ \\
\hline $\mathbf{4}$ & $\mathbf{S 4}$ & $1.00 \pm 0.07$ & $0.14 \pm 0.09$ & $0.07 \pm 0.02$ & $0.06 \pm 0.02$ & $0.10 \pm 0.02$ & $0.05 \pm 0.02$ & $0.01 \pm 0.00$ \\
\hline $\mathbf{5}$ & $\mathbf{S 5}$ & $0.34 \pm 1.00$ & $2.00 \pm 0.04$ & $0.08 \pm 0.01$ & $0.03 \pm 0.02$ & $0.06 \pm 0.03$ & $0.05 \pm 0.00$ & $0.02 \pm 0.01$ \\
\hline $\mathbf{6}$ & $\mathbf{S 6}$ & $0.29 \pm 0.11$ & $1.23 \pm 0.08$ & $0.01 \pm 0.05$ & $0.01 \pm 0.03$ & $0.02 \pm 0.04$ & $0.04 \pm 0.01$ & $0.00 \pm 0.01$ \\
\hline $\mathbf{7}$ & $\mathbf{S 7}$ & $0.08 \pm 0.02$ & $0.12 \pm 1.02$ & $0.00 \pm 0.01$ & $0.01 \pm 0.02$ & $0.00 \pm 0.01$ & $0.02 \pm 0.00$ & $0.00 \pm 0.00$ \\
\hline $\mathbf{8}$ & $\mathbf{S 8}$ & $0.10 \pm 0.03$ & $0.11 \pm 0.09$ & $0.01 \pm 0.01$ & $0.02 \pm 0.02$ & $0.01 \pm 0.02$ & $0.00 \pm 0.01$ & $0.00 \pm 0.00$ \\
\hline $\mathbf{9}$ & $\mathbf{S 9}$ & $2.06 \pm 1.00$ & $2.01 \pm 0.06$ & $0.06 \pm 0.02$ & $0.06 \pm 0.01$ & $0.03 \pm 0.00$ & $0.05 \pm 0.01$ & $0.02 \pm 0.01$ \\
\hline $\mathbf{1 0}$ & $\mathbf{S 1 0}$ & $1.04 \pm 1.01$ & $3.03 \pm 0.02$ & $0.07 \pm 0.03$ & $0.03 \pm 0.06$ & $0.09 \pm 0.01$ & $0.06 \pm 0.01$ & $0.02 \pm 0.00$ \\
\hline
\end{tabular}

Results are expressed in mean $\pm \mathrm{SD}$, test were carried out in triplicate.

The concentration of carbonate, nitrate and nitrite found in all tested water samples were low compare to the WHO acceptable limit. Nitrate is found in the highest levels in ground water under extensively developed areas. it enters the environment from fertilizer, feedlots, and sewage. Nitrite on the other hand enters environment from fertilizer, sewage, and human or farm-animal waste. Toxicity of both causes "bluebaby disease," or methemoglobinemia, which threatens oxygen-carrying capacity of the blood.

The $\mathrm{Cu}$ level for the well water sample ranged from $0.00 \pm 0.001$ to $0.06 \pm 0.01$ and fell within the maximum permissible limit by WHO (2.00). Pb content in sample 5, 9 and 10 was high $(0.002 \mathrm{mg} / \mathrm{L})$ compared to other samples and it exceed the WHO guideline $(0.01 \mathrm{mg} / \mathrm{L})$ but within that of USEPA $(1.00)$. Iron Occurs naturally as a mineral from sediment and rocks or from mining, industrial waste, and corroding metal. Sample 4 has the highest iron concentration level among all samples tested, though the high level of iron concentration in the water does not exceed the acceptable WHO limit. Zinc concentration in sample 4 and 9 are the highest while sample 6 and 7 has the lowest zinc concentration. Zinc aids in the healing of wounds and Causes no ill health effects except in very high doses it alsoimparts an undesirable taste to water,toxic to plants at high levels.

\section{Conclusion:-}

Findings from this study, showed that the physiochemical parameters and the few heavy metals tested were consistent with World Health Organization standard for drinking water (WHO). The samples were analyzed for intended water quality parameters following internationally recognized and well established analytical techniques. 


\section{Refrences:-}

1. Asonye CC, Okolie NP, Okenwa EE,Iwuanyanwu UG (2007). Some Physico- chemical characteristics and heavy metal profile of Nigerian rivers, streams and waterways. Afr. J. Biotechnol. 6(5): 617-624.

2. Boswinkel JA (2000). Information Note, International Groundwater Resources Assessment Centre (IGRAC), Netherlands Institute ofApplied Geoscience, Netherlands. In: UNEP (2002), Vital Water Graphics - An Overview of the State of the Wor ld's Fresh and Marine Waters, UNEP, Nairobi, Kenya.

3. UNEP (United Nations Environment Programme), (2002). Global Environment Outlook (GEO-3): 416.

4. Herschy RW (1999). Hydrometry Principles and and Practices ( $2^{\text {nd }}$ Edition) John Wiley \& Sons, Chicchester.

5. Jackson et al (2001) Water in changing world, Issues in Ecology. Ecol Soc Am, Washington, pp 1-16 